Omar Z. AL-Tahho BDS,MSc, (Asst. Lect)

\section{Effect of Dry Pressure Heat Curing Technique on Water Sorption and Color of Heat Cured Acrylic Resin}

\author{
Department of Prosthetic Dentistry
}

College of Dentistry, University of Mosul

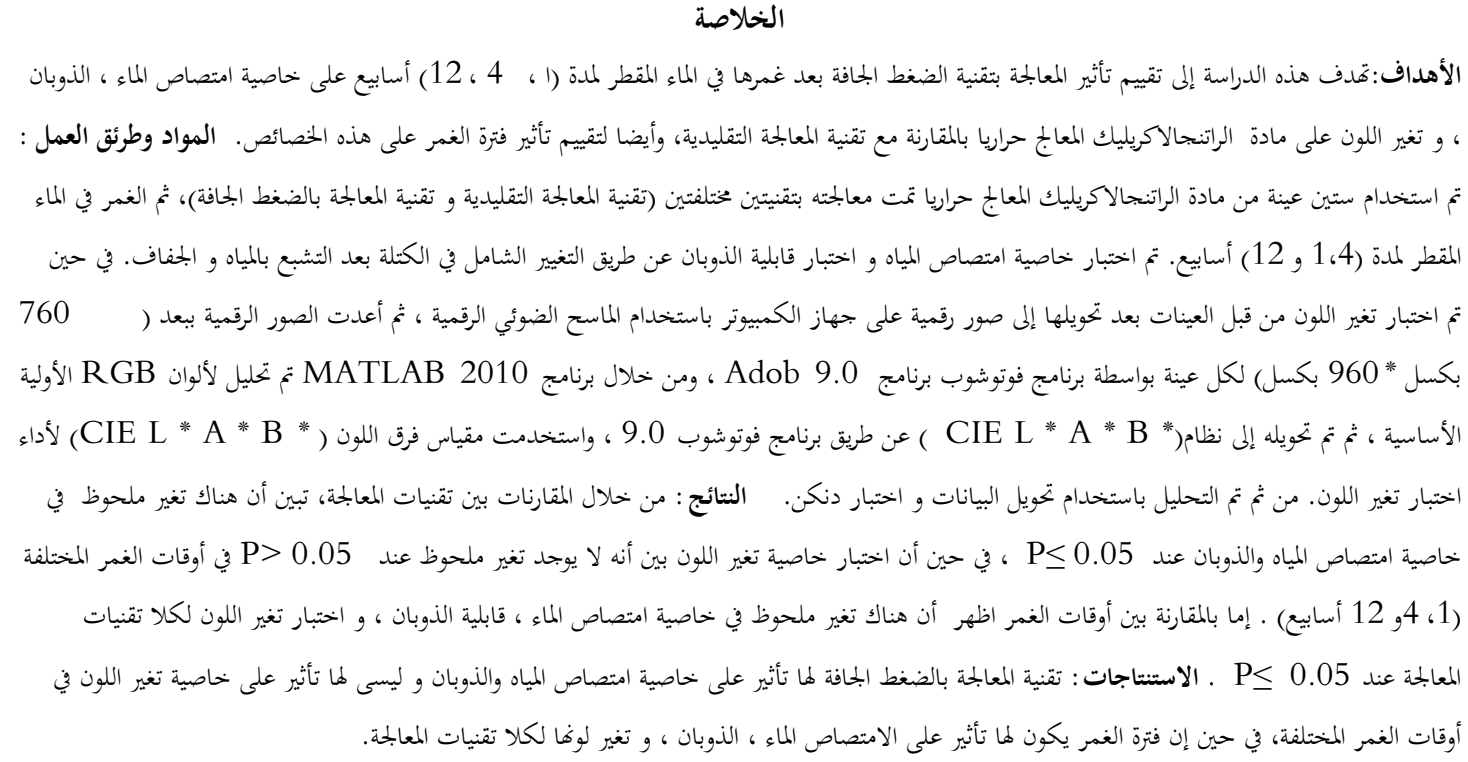

\begin{abstract}
Aims: The purpose of this study was to evaluate the effect of dry pressure curing technique after immersion in distilled water for 1,4 and 12 weeks on the water sorption, solubility, and color change of heat cured acrylic resin as compared with conventional curing technique, also to evaluate the effect of immersion period on these properties. Materials and methods: Sixty specimens of vertex regular heat cured acrylic resin denture base material were used in this study, curing by two different technique, conventional curing technique and dry pressure curing technique, then immersed in distilled water for 1,4 , and 12 week. The water sorption and solubility test were measured by means of mass change in the materials after water saturation and dehydration. While the color change test was measured by the samples converted to digital images on computer by using digital scanner, then the digital images were prepared with dimension 760 pixels*960 pixels for each samples by software program Adob Photoshop 9.0, by MATLAB 2010 program the image was analyzed to the basic primary colors RGB, then converted to (CIE L*a*b*) system by Photoshop 9.0 program, the CIE $\mathrm{L}^{*} \mathrm{a} * \mathrm{~b} *$ color difference metric were used to perform color change test. Mean values were compared statistically with T-test, one way analysis of variance and by Duncan's multiple range test to determined the significant different among the groups at $\mathrm{p}<0.05$ level of significance. Results: In comparisons between curing techniques, that there was significant difference at $p \leq 0.05$ in water sorption and solubility, while in color change that there was no significant difference at $\mathrm{P}>0.05$ in different times immersion $(1,4$,and 12 weeks). In comparisons between immersion time that there was significant difference at $p \leq 0.05$ in water sorption, solubility, and color change test for both curing techniques. Conclusion: The dry pressure curing technique has an effect on the water sorption and solubility ratios but no effect on color change of heat cured acrylic resin, while the immersion period have an effect on the water sorption, solubility, and color change.
\end{abstract}

Key words: sorption, solubility, color change, pressure curing units

AL-TahhoOZ, Effect of Dry Pressure Heat Curing Technique on Water Sorption and Color of Heat Cured Acrylic Resin. Al-Rafidain Dent J. 2014; 14(2):294-301.

$\begin{array}{ll}\text { Received: 6/5/2013 Sent to Referees: 7/5/2013 Accepted for Publication:25/6/2013 } & \text { A } 3 \text { A }\end{array}$ 


\section{INTRODUCTION}

Polymethyl methacrylate is the most used acrylic resin and is characterized as being strong, having satisfactory optical properties, copying oral tissue appearance, showing low water sorption and solubility to oral tissues, no other material has been found that matches the appearance of the oral soft tissues with as great as fidelity as acrylic resin. ${ }^{(1)}$ Curing processes have been modified in order to improve the physical and mechanical properties of those materials, and also to afford the technical work of the professionals. Different polymerization methods have been used: heat, light and microwave energy. ${ }^{(2)}$

Sorption of material represents the amount of water adsorbed on the surface and absorbed into the body of the material. The sorption of poly methyl methacrylate (PMMA) is facilitated by its polarity and the mechanism primary responsible for ingress of water is diffusion. ${ }^{(3)}$ High equilibrium uptake of water can soften a denture because the absorbed water can act as a plasticizer of (PMMA) and reduce the strength of the material. ${ }^{(4)}$ Whereas solubility represents the mass of the soluble materials from polymer. The only soluble materials presented in the denture base resins are initiator, plasticizers and free monomer. ${ }^{(5,6)}$ High solubility is not a favorable characteristic for denture materials. The denture base resins are completely insoluble in water and in most fluids that come in contact with the resin in the oral cavity. Any observed loss of weight of the resin is a measure of the specimen solubility. ${ }^{(6)}$ The phenomena of sorption and solubility producing deleterious effects, these effects may include volumetric changes such as swelling, physical changes such as plasticization and softening, and chemical changes such as oxidation and hydrolysis and color change. ${ }^{(7)}$

Color stability is the property of a material that allows color to be maintained over a period of time in a given environment. It is considered an important physi- cal property of dental materials. ${ }^{(8)}$ Color change in acrylic resins can result from intrinsic and extrinsic factors. ${ }^{(9,10)}$ Intrinsic discoloration is due to the aging of material, which results from exposure to physical and chemical conditions that involve thermal changes and humidity. ${ }^{(11)}$ Extrinsic factors, such as absorption and adsorption, can promote discoloration. ${ }^{(12,13)}$

poly methyl methacrylate resins were molded by using simple compression technique. Polymerization was accomplished by heating the molded material in water bath, with advances in polymer science, new molding and activation techniques have been introduced such as visible light cured, microwave and ivomat activation techniques. ${ }^{(14)}$ Dry pressure curing technique are new method for curing heat cured acrylic, there was no previous publish articles concerning the properties of heat cured acrylic cured by this method so, the purpose of this study was to evaluate the effect of dry pressure curing technique after immersion in distilled water for 1,4 , and 12 weeks on the water sorption, solubility, and color change of heat cured acrylic as compared with conventional curing technique, also to evaluate the effect of immersion period onthese properties.

\section{MATERIALS AND METHODS}

Sixty specimens of heat cured acrylic resin denture base material (Vertex Regular, Holland) were used in this study, curing by two different technique, conventional curing technique (as control) and dry pressure curing technique. The heat cured acrylic resin was selected to evaluate the influence of two different methods of curing technique on the water sorption, solubility, and color change properties of these material after immersion in distilled water for 1,4 and 12weeks. Pressure curing units (Lingchen) was used in this study at 600 Watt for 25 minutes (according to the manufacturer instructions) as shown in Figure (1). 


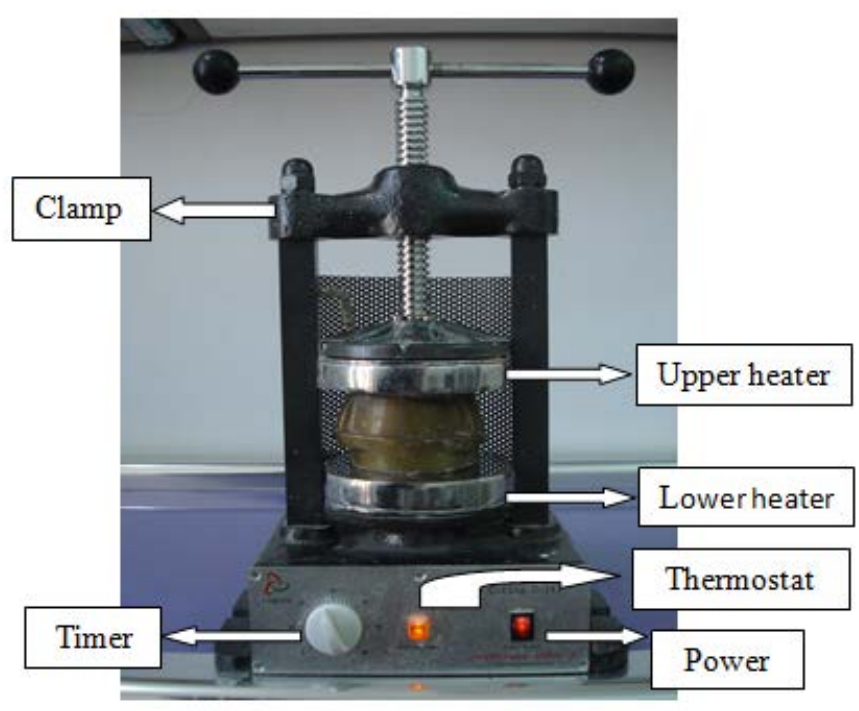

Figure(1): Pressure curing units.

Powder (polymer) and liquid (monomer) of heat cured acrylic resin have been mixed according to the manufacturer's instruction and packed into stone mold in the metal flask, then the flask was re-closed and pressed under a hydraulic press 100 bar for fifteen minutes. For conventional curing technique the specimens were cured by water bath according to its manufacturer's instruction (90 mints in $73^{\circ} \mathrm{C}$ then 30 mints in $100^{\circ} \mathrm{C}$ ). While in dry pressure curing technique, the specimens were cured for 30 min in pressure curing units at $104^{\circ} \mathrm{C}$, then switch off and the flask removed from device (according to manufacturer instructions of device), then the flasks were left aside for bench cooling at room temperature before opening; the samples have been removed, finished with engine stone bur.

\section{Water sorption and water solubility test}

Thirty disk specimens were prepared by using a stainless steel die with dimensions of $50 \mathrm{~mm} \pm 1 \mathrm{~mm}$ diameter and $0.5 \mathrm{~mm} \pm 0.1 \mathrm{~mm}$ for thickness. ${ }^{(15)}$ For sorption test, the specimens were dried in a desiccators containing freshly dried silica gel arranged according to their group and separated by filter paper. Then, the desiccators was stored in an incubator at $37 \pm 1^{\circ} \mathrm{C}$ for 24 hours. The specimens were removed to a similar desiccators at room temperature for one hour then weighed to an accuracy of $0.001 \mathrm{gm}$ using a digital electronic balance device (Mettler PM 460, Germany). This cycle was repeated every 24 hours until a constant mass (W1) was reached. Then, the specimens were immersed in distilled water for 1,4 and 12 weeks at $37 \pm 1^{\circ} \mathrm{C}$, then all test groups the disks were removed from distilled water with tweezers and wiped with a clean dry towel until free from moisture and weighed this mass was recorded as (W2), this represent the weight of the specimen after absorption of distilled water. After that to obtain the value of solubility test, the disks were reconditioned to a constant mass in the desiccators at $37 \pm 1^{\circ} \mathrm{C}$ as done previously for sorption test and the constant reconditioned mass was recorded as (W3). The absorption and solubility values were determined as follows: ${ }^{(16-18)}$

Absorption $=[(\mathrm{W} 2-\mathrm{W} 3) / \mathrm{W} 1] * 100$

Solubility $=[(\mathrm{W} 1-\mathrm{W} 3) / \mathrm{W} 1]^{*} 100$

\section{Color Change Test}

Thirty specimens were prepared by using a Hard elastic foil (Easy-Vac Gasket) with uniform dimensions of $30 * 20 * 1.5 \mathrm{~mm} \pm 1 \mathrm{~mm}$ (length, width, and thickness respectively). ${ }^{(19)}$ The samples converted to digital images on computer by using digital scanner (CanoScanLiDE 100, Canon solutions). The images were digitized, with an input resolution of 1200 pixels per inch. ${ }^{(20)}$ These digital images were prepared with dimension 760 
pixels*960 pixels for each samples (exclude label on sample) by software program Adob Photoshop 9.0. Then these images were saved, by MATLAB 2010 program. Then each image was analyzed to the basic primary colors RGB (red, green, and blue) then given mean values. Primary colors RGB values converted to CIE L*a*b* system by Photoshop 9.0 program. CIE L*a*b* color difference metric were used to perform color change test by using Photoshop 0.9 program to obtain the baseline $\mathrm{L}^{*}, \mathrm{a}^{*}, \mathrm{~b}^{*}$ values and the total color change $(\Delta \mathrm{E})$ of each samples was calculated for each sample at each evaluation using the following formula: ${ }^{(21,22)}$

$$
\begin{gathered}
\Delta \mathrm{E}=\left[(\mathrm{L} * 2-\mathrm{L} * 1)^{2}+\left(\mathrm{a}^{*} 2-\mathrm{a}^{*} 1\right)^{2}+\right. \\
\left.\left(\mathrm{b} * 2-\mathrm{b}^{*} 1\right)^{2}\right]^{1 / 2} \\
(\mathrm{~L} * 1, \mathrm{a} * 1, \mathrm{~b} * 1=\text { before immersion, } \mathrm{L} * 2, \\
\mathrm{a} * 2, \mathrm{~b} * 2=\text { after immersion })
\end{gathered}
$$

$\Delta \mathrm{E}$ value of (3.7) or less is considered to be clinically acceptable in vitro study and of (6.8) is considered to be clinically acceptable in vivo study. ${ }^{(21,23)}$ The mean and standard deviation were calculated. T-test, One way analysis of variance and Duncan's multiple rang test were used to analyze the data and to determine the level of significant difference among the test groups at $\mathrm{P} \leq 0.05 \%$ level of significant.

\section{RESULTS}

water sorption and solubility

Tables (1 and 3) demonstrated the ttest values in comparisons between curing techniques of heat cured acrylic resin that showed significant difference at $\mathrm{p} \leq 0.05$ in water sorption and solubility between dry pressure curing technique with conventional curing technique for heat cured acrylic resin in different times immersion (1,4, and 12 weeks),that the water sorption and solubility in dry pressure curing technique higher than conventional curing technique.

ANOVA test as shown in Tables (2 and 4) and Duncan's multiple range test Figures ( 2 and 3) demonstrated that there was significant difference at $p \leq 0.05$ in the water sorption and solubility between different times immersion for both techniques. The water sorption and solubility for samples that immersion for 12 weeks

\begin{tabular}{|c|c|c|c|c|c|c|c|}
\hline S & Type of curing & No. & Mean & Std. Deviation & T. Value & Df & $P$. Value \\
\hline \multirow{2}{*}{1 Week } & Conventional & 5 & 1.8710 & 0.02655 & \multirow{2}{*}{-29.280} & \multirow{2}{*}{8} & \multirow{2}{*}{$0.000 *$} \\
\hline & Dry Pressure & 5 & 2.2260 & 0.00548 & & & \\
\hline \multirow{2}{*}{4 Week } & Conventional & 5 & 2.2450 & 0.00500 & \multirow{2}{*}{-58.294} & \multirow{2}{*}{8} & \multirow{2}{*}{$0.000^{*}$} \\
\hline & Dry Pressure & 5 & 2.3760 & 0.00548 & & & \\
\hline \multirow{2}{*}{ 12Week } & Conventional & 5 & 2.3550 & 0.00500 & \multirow{2}{*}{-66.634} & \multirow{2}{*}{8} & \multirow{2}{*}{$0.000 *$} \\
\hline & Dry Pressure & 5 & 2.5760 & 0.00548 & & & \\
\hline
\end{tabular}
in both curing techniques higher as compared with other immersion periods.

Table (1): Water sorption of dry pressure and conventional curing techniques (T- test).

Table (2): ANOVA of water sorption between times immersion of heat cured acrylic resin in two curing techniques.

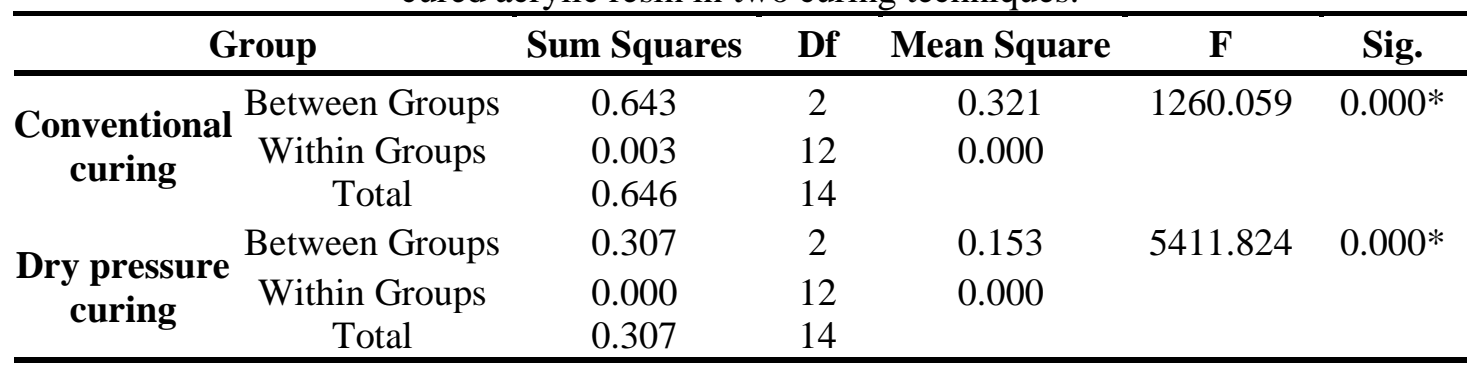


Table (3):Water solubility of dry pressure and conventional curing techniques (T- test).

\begin{tabular}{cccccccc}
\hline Time & Type of curing & No. & Mean & Std. Deviation & T. Value & Df & P. Value \\
\hline \multirow{2}{*}{$\mathbf{1}$ Week } & Conventional & 5 & 0.60280 & 0.039613 & -5.050 & \multirow{2}{*}{8} & \multirow{2}{*}{$0.001^{*}$} \\
& Dry Pressure & 5 & 0.71260 & 0.028192 & & & \\
\multirow{2}{*}{$\mathbf{4}$ Week } & Conventional & 5 & 0.83040 & 0.041180 & -2.975 & 8 & $0.018^{*}$ \\
& Dry Pressure & 5 & 0.90480 & 0.037831 & & & \multirow{2}{*}{$\mathbf{1 2 W e e k}$} \\
& Conventional & 5 & 0.89500 & 0.005000 & -31.623 & 8 & $0.000^{*}$ \\
\hline
\end{tabular}

Table (4): ANOVA of water solubility between times immersion of heat cured acrylic resin in two curing techniques.

\begin{tabular}{ccccccc}
\hline \multicolumn{2}{c}{ Group } & Sum Squares & Df & Mean Square & F & Sig. \\
\hline \multirow{2}{*}{$\begin{array}{c}\text { Conventional } \\
\text { curing }\end{array}$} & Between Groups & 0.236 & 2 & 0.118 & 107.413 & $0.000^{*}$ \\
& Within Groups & 0.013 & 12 & 0.001 & & \\
\multirow{2}{*}{$\begin{array}{c}\text { Dry pressure } \\
\text { curing }\end{array}$} & Total & 0.249 & 14 & & & \\
& Between Groups & 0.208 & 2 & 0.104 & 138.635 & $0.000^{*}$ \\
& Within Groups & 0.009 & 12 & 0.001 & & \\
\hline
\end{tabular}

From Tables (1-4) : * Significant difference at $\mathrm{p} \leq 0.05$.

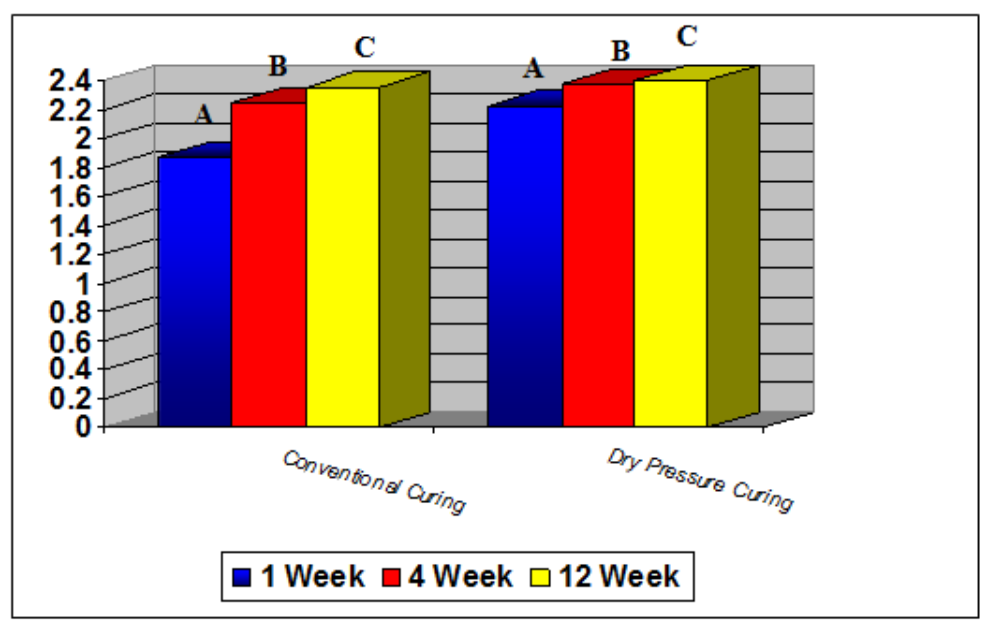

Figure (2): Duncan's multiple range test of water sorption for different times of immersion.

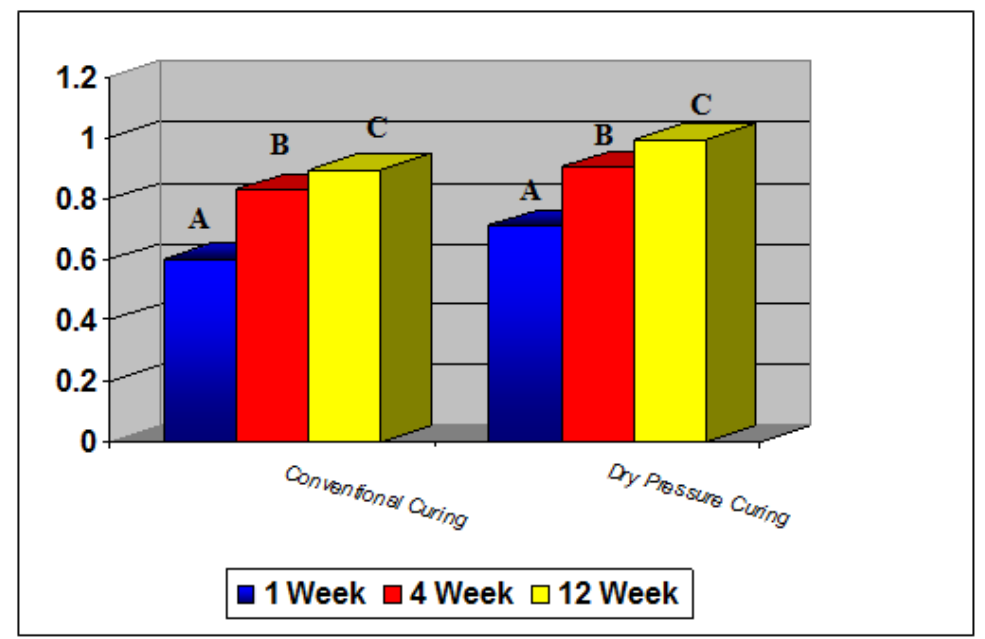

Figure (3): Duncan's multiple range test of water solubility for different times of immersion. 
Color Change ( $\triangle E)$

Table (5) demonstrated the t- test values in comparisons between curing techniques of heat cured acrylic resin that showed no significant difference at $\mathrm{P}>0.05$ in color change between dry pressure curing technique with conventional curing technique for heat cured acrylic resin in different times immersion (1, 4, and 12 weeks).

Table (5): Color change of dry pressure and conventional curing techniques (T- test).

\begin{tabular}{cccccccc}
\hline Time & Type of curing & No. & Mean & SD & T.Value & Df & P.Value \\
\hline \multirow{2}{*}{$\mathbf{1}$ Week } & Conventional & 5 & 0.4440 & 0.39929 & -0.350 & \multirow{2}{*}{8} & \multirow{2}{*}{0.735} \\
& Dry Pressure & 5 & 0.5120 & 0.17152 & & & \\
\multirow{2}{*}{ Week } & Conventional & 5 & 0.8460 & 0.41223 & -0.585 & \multirow{2}{*}{8} & 0.574 \\
& Dry Pressure & 5 & 0.9840 & 0.32853 & & & \multirow{2}{*}{$\mathbf{1 2 W e e k}$} \\
& Conventional & 5 & 1.4020 & 0.66039 & -1.090 & 8 & 0.307 \\
\hline
\end{tabular}

No significant difference at $\mathrm{p}>0.05$

ANOVA test as shown in Table (6) and Duncan's multiple range test Figure (4) demonstrated that there was significant difference at $\mathrm{P} \leq 0.05$ in the color change between different times immersion for both curing techniques. The color change for samples that immersion for 12 weeks in both curing techniques higher as compared with other immersion periods.

Table (6): ANOVA of color change between times immersion of heat cured acrylic resin in two curing techniques.

\begin{tabular}{|c|c|c|c|c|c|c|}
\hline \multicolumn{2}{|c|}{ Group } & Sum Squares & Df & Mean Square & $\mathbf{F}$ & Sig. \\
\hline \multirow{3}{*}{$\begin{array}{l}\text { Conventional } \\
\text { curing }\end{array}$} & Between Groups & 2.314 & 2 & 1.157 & 4.535 & $0.034^{*}$ \\
\hline & Within Groups & 3.062 & 12 & 0.255 & & \\
\hline & Total & 5.376 & 14 & & & \\
\hline \multirow{2}{*}{$\begin{array}{c}\text { Dry } \\
\text { pressure curing }\end{array}$} & Between Groups & 4.373 & 2 & 2.187 & 15.292 & $0.001 *$ \\
\hline & Within Groups & 1.716 & 12 & 0.143 & & \\
\hline
\end{tabular}

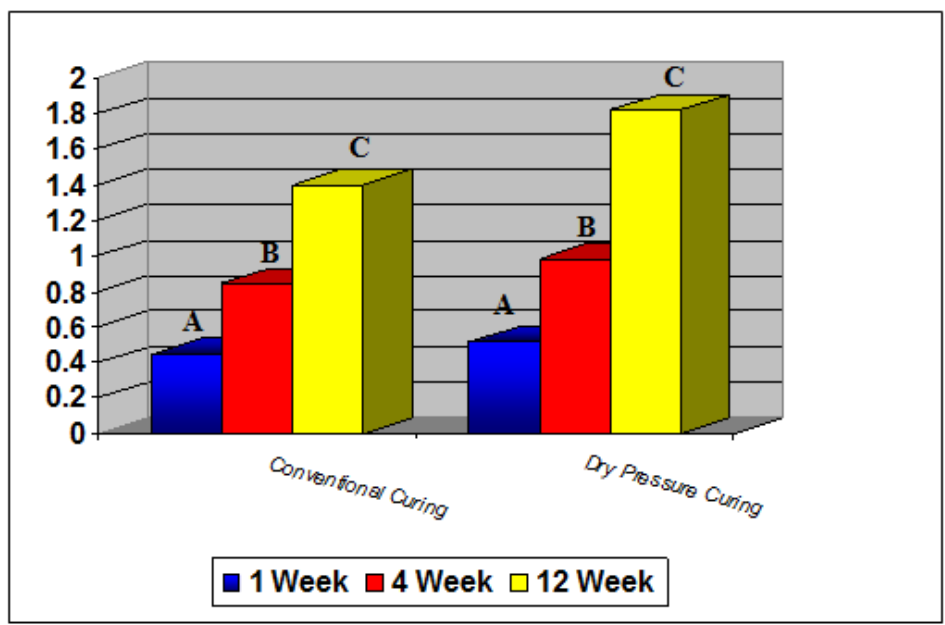

Figure (4): Duncan's multiple range test of color change for different times of immersion.

\section{DISCUSSION}

water sorption and solubility:

All samples of acrylic resin used in this study demonstrated water sorption and solubility after storage in water (Tables 1-4). Sorption can be related to the polarity of acrylic resin(due to unsaturated bond). ${ }^{(24)}$ While, solubility can be related to the leach of soluble material that present in an acrylic resin (initiator, plasticizer, residual monomer). ${ }^{(25)}$

Table (1and 3) demonstrated that the 
water sorption and solubility in dry pressure curing technique higher than conventional curing technique. In this study that the time and temperature for curing different between both techniques. This result comes in agreement with the finding of Janaina et al.,(2003) ${ }^{(26)}$ in that the method of polymerization has decisive feature on the physical properties of the cured resin. They reported a correlation between the polymerization temperature and time, and water sorption and solubility, depending on the polymerization temperature and time, various quantities of residual monomer are left in the polymer. If residual monomer is present, less monomer conversion occurs and may result in increased sorption and solubility. ${ }^{(27)}$

Tables (2and 4) and Figure (2 and 3), demonstrated that there was a significant increase in water sorption and solubility with increase times for immersion $(1,4$, and 12 weeks) for both curing techniques, this results is agreement with $\mathrm{Al}-$ Nori et al., (2007) ${ }^{(28)}$ who concluded that the immersion period have an effect on the water sorption and solubility ratios of the different types of heat cured acrylic resin, also agreement with Van (2002) ${ }^{(29)}$ who found that the water sorption is gradual process taking many months to complete.

\section{Color Change ( $\triangle E)$ :}

Table (5) demonstrated no significant difference in color change between the two curing techniques in different times immersion (1, 4, and 12 weeks), this result come in agreement with Assunçao et al.,(2009) ${ }^{(30)}$ who concluded that the color of heat cured acrylic resin teeth was not affected by the polymerization methods.

in Table (6) and Figure (4) demonstrated that there was a significant increase in color change with increase times for immersion $(1,4$, and 12 weeks) for both curing techniques, due to water sorption and solubility that affect color of heat cured acrylic resin at different times immersion. The water sorption has detrimental effect on the color stability. ${ }^{(29)}$ Water plays an important role in chemical degradation processes such as oxidation and hydrolysis and the subsequent change of the optical properties of the dental polymer materials. ${ }^{(31)}$

\section{CONCLUSION}

This study comes up with the following conclusions:

1. The method of curing technique and immersion period have an effect on the water sorption and solubility ratios of heat cured acrylic resin.

2. The immersion period have an effect on the color change $(\Delta \mathrm{E})$ of heat cured acrylic within accepted color change $(\Delta \mathrm{E}$ $\leq 3.7$ ) in vitro study.

3 . The type of curing technique have no effect on color change $(\Delta \mathrm{E})$.

\section{REFERENCES}

1. Spencer HR, Gariaef FP. The present status of vulcanite versus plastics as a base plate material. Dent Mater $J$ .1949; 27(28):263-267.

2. Garcia RC, Junior JA, Rached RN. Effect of denture cleanser on the surface roughness and hardness of a microwave cured acrylic resin and dental alloys. J Prosthet Dent.2004; 13: 173-178.

3. Anusavice KJ. Philips science of dental materials. 10th ed. Philadelphia, WB Saunders Co. 1996; Pp:211-235, 237-271.

4. Gilber AS, Pethrik RA, Phillips DW. Acostic relaxation and infrared spectroscopic measurements of the plasticization of polymethylmethacrylate by water .J Applpolym Sci. 1977;21:319-330.

5. Craig RG, Powers JM. Restorative dental materials.11th edition. St. louis:mosby. 2002; Pp: 635-689.

6. Phillips RW. Skinners Science of dental materials. 7th ed. Saunders Company, Philadelphia. 1973; Pp: 177-213.

7. Nicolas M, Nicolas M J, Antony CF. Hygroscopic and hydrolytic effects in dental polymer networks. Dent Mater J.2006 ; 22: 211-222.

8. Hong G, Murata H, Li Y, Sadamori S, Hamada T. Influence of denture cleansers on the color stability of three types of demture base acrylic resin. $J$ Prosthet Dent.2009;101:205-213.

9. Villalta P, Lu H, Okte Z, Garcia-Godoy F, Powers JM. Effects of staining and 
bleaching on color change of dental composite resins. J Prosthet Dent. 2006;95:13742.

10.Minami H, Hori S, Kurashige $H$, Murahara S, Muraguchi K, Minesaki Y. Effects of thermal cycling on surface texture of restorative composite materials. Dent Mater J. 2007;26: 316-338.

11.Iazzetti G, Burgess JO, Gardiner D, Ripps A. Color stability of fluoridecontaining restorative materials. Oper Dent J. 2000;25:520-525.

12. Abu-Bakr N, Han L, Okamoto A. Color stability of compomer after immersion in various media. $J$ Esthet Dent. 2000;12:258-263.

13.Hersek N, Canay S, Uzun G, Yildiz F. Color stability of denture base acrylic resins in three food colorants. J Prosthet Dent. 1999;81:375-384.

14. Schlosberg SR, Goodacre CJ, Manoz CA, Moore BK, Schnell RJ. Microwave energy polymerization of Poly methylmethacrylate denture base resin. Int J Prosthodont.1989;2: 453.

15.American Dental Association Specification. Guide to dental materials and device.7th ed. 1975; Pp: 203-208.

16.Gregory RP, Frederick AR. In Vitro Hardness, Water Sorption and ResinSolubility of Laboratory- Processed and Auto Polymerized Long-Term Resilient Denture Liners Over One Year of Water Storage. J Prosthet Dent. 2002; 88: 139-144.

17.Blanca L, Altair A. Water Sorption, Solubility and Tensile Bond Strength of Resilient Denture Lining Materials Polymerized by Different Method After Thermal Cycling. J Prosthet Dent. 2005; 93: 282-287.

18.Ammar K, Ahmad MA, Lamia T. Water Sorption of Heat-Cured Acrylic Resin. Al-Rafidain Dent J.2007;7:186194.

19.Hatim NA, Taqa AA, Hasan RH. Evaluation of the effect of curing techniques on color property of acrylic resins. Al-Rafidain Dent J. 2004; 4(1):28-33.
20.Rejab LT. Digital analysis of the color of the heat-cured acrylic resin (using scanner). Al-Rafidain Dent $J$. 2011;11(1): 88-95.

21. Alvin GW, Delwin TL, Shanglun K. Color accuracy of commercial digital cameras for use in dentistry. Dent mater J. 2006; 6(22):553-559.

22. Monica A, Pratheek S, Sudhakar GB. Shade matching in fixed prosthodontics using instrumental color measurements and computers. J Ind Prosth Soc.2007; 4(7): 179-183.

23. Arthur SK, Frederik CS, Jhon FK. Color stability of provisional prosthodontic materials. J Prosthet Dent.2004; 5(91): 447-452.

24.Philips RW. Skinners Science of Dental Materials. 9th Ed. WB Saunders Philadelphia. 1991; Pp: 177-213.

25.Takashi A, Hiroshi M, Taizo H. Prperties of Highly Cross-Linked Auto Polymerizing Reline Acrylic Resins. $J$ Prosthet Dent.1995;73:55-59.

26.Janaina H, Eunice TG, Carlos EV. Cytotoxicity of denture base acrylic resins: A literature review. J Prosthet Dent. 2003;90:190-193.

27.Doğan A, Bek B, Çevik NN, Usanmaz A. The effect of preparation conditions of acrylic denture base materials on the level of residual monomer, mechanical properties and water absorption. $J$ of Dentistry. 1995;23(5):313-318.(IVSL)

28.Al- NoriAKh, Ali AA, Rejab LT. Water sorption of heat cured acrylic resin. Al-Rafidain Dent J. 2007; 7(2): 186-194.

29.Van Nort R. Introduction to Dental Materials. 2d ed. Mosby Co. Missouri, USA. 2002; Pp: 96-112.

30.Assunçao WG, Barao VA, Pita MS, Goiato MC . Effect of polymerization methods and thermal cycling on color stability of acrylic resin denture teeth. $J$ Prosthet Dent. 2009; 102:385-392

31.Ruyter IE. Physical and chemical aspects related to substances released from polymer materials in an aqueous environment. Adv Dent Res J. 1995;9:344-350. 